\title{
Condicionantes sociais do projeto de instrumentos de trabalho: o caso de uma bancada de inspeção
}

Francisco de Paula Antunes Lima UFMG

Adson Eduardo Resende UFMG

Renata Campos Vasconcelos PUC-MG

RESUMO

A natureza social dos objetos é reconhecida nos aspectos formais ou estéticos, e nem sempre gera diretrizes para o design no aspecto funcional. Recentemente, as dimensões cognitivas têm sido incorporadas aos projetos de produto. 0 propósito deste artigo é discutir e demonstrar a importância das interações sociocognitivas no projeto de instrumentos de trabalho no nível de relações físicas, sempre tratados segundo modelos biomecânicos e variáveis fisiológicas. Tomando como exemplo o projeto de bancada de inspeção de produtos farmacêuticos, mostramos como esse projeto, para se ajustar aos modos operatórios, teve que atender os condicionantes intersubjetivos do contexto social no qual se insere a atividade.

\section{Social conditions of work instruments design: the case of a pharmaceutics inspection workstation}

\section{ABSTRACT}

The social nature of objects is recognized in their formal or aesthetic aspects, but this does not always generate guidelines for design in the functional aspect. Recently, cognitive dimensions have been incorporated into product design. Our intention in this article is to argue and demonstrate the importance of socio-cognitive interactions in the design of work instruments at the level of physical relations, always treated in accordance with biomechanical models. Taking as example the design of a work station for pharmaceutical products inspection, we show how the design had also to take into account the subjective conditioners derived from the social context in which the activity occurs.

\section{KEY WORDS}

Ergonomics conception, social form of instruments, participatory project 


\section{PARADIGMAS DE PROJETO PARTICIPATIVO}

Este artigo relata a experiência de adequação de um posto de trabalho à atividade dos trabalhadores, em um processo participativo de projeto conduzido por ergonomistas, desenhistas industriais e engenheiros. Para bens de consumo, há uma demanda crescente por produtos diversificados e customizados, caracterizando-se uma nova economia de escopo, em contraposição à economia de massa. As empresas e a produção vivem, em consequência, sob forte pressão para incorporar a perspectiva do usuário na concepção dos produtos, tendência que gradativamente se estende ao projeto dos ambientes de trabalho, surgindo metodologias participativas, equipes multifuncionais e a presença da "voz do cliente interno". Esse interesse é reforçado, às vezes diretamente motivado, por exigências legais de saúde ocupacional e programas de melhoria da qualidade de vida no trabalho. Da perspectiva acadêmica, esse movimento motivou, nas áreas de design e engenharia de produção, pesquisas teóricas e novos arranjos metodológicos, que podem ser organizados em torno de três eixos(1):

1) Projeto centrado no consumidor/cliente: Em um primeiro momento procurou-se recolocar o consumidor/ cliente no centro do processo de desenvolvimento de produtos, através de estratégias de marketing, fidelização, pesquisa de opinião e participação direta do cliente, desenvolvimento in home, respeito ao consumidor, melhoria da qualidade e da confiabilidade dos produtos, customização e desenvolvimento de produtos personalizados. O princípio fundamental dessa abordagem é a contribuição da presença, física ou pensada, do consumidor/cliente desde o início da concepção e durante todas as etapas de desenvolvimento - para uma apresentação deste modelo e sua crítica, ver Norman (1998).

2) Projeto centrado nas necessidades dos usuários/ clientes: A reviravolta da qualidade também recoloca o cliente no centro da produção e do desenvolvimento de produtos, considerando desta vez tanto o cliente interno quanto o externo. Nesse caso já se nota um avanço em relação ao reconhecimento das necessidades dos trabalhadores enquanto usuários ou parte integrante de um processo de produção. Nesse nível, surge uma série de demandas que colocam questões teóricas e metodológicas inéditas, para viabilizar projetos que atendam as reais necessidades dos clientes/usuários. Primeiramente, dar "voz aos clientes" exige organizar a participação e criar condições para expressão de suas necessidades reais; num segundo momento, essas demandas, reconhecidas e formalizadas, devem ser traduzidas em parâmetros operacionais no universo da engenharia; finalmente, as necessidades dos usuários/clientes/consumidores terão que se defrontar com outras exigências (custo, processos de fabricação, materiais, métodos de produção, escala de produção, tempo de resposta, competências da mão-de-obra...). Trata-se de viabilizar a presença efetiva do cliente no processo de desenvolvimento de produtos e no processo de produção, e não apenas assegurar sua presença física ou imaginada (as referências aqui são, evidentemente, as abordagens do quality function deployement - QFD; uma elaboração teórica das diferentes perspectivas dos atores envolvidos no projeto pode ser encontrada em Bucciarelli (1994) e no conceito de "objeto-mundo".
3) Projeto centrado na atividade de utilização: Outro conjunto de problemas diz respeito à utilização efetiva dos produtos e serviços. As relações antes consideradas em termos de categorias de "cliente", "consumidor" ou "usuário" manifestam-se agora em práticas, na utilização cotidiana do produto ou posto de trabalho. Não é indiferente que o sujeito seja convocado a participar do processo de projeto como um sujeito falante, capaz de expressar opiniões e necessidades, ou como um sujeito que, além da ação comunicativa, interage com o produto ou instrumento de trabalho em uma atividade prática. Ele interage com o objeto de múltiplas formas, como proprietário, como apreciador estético, mas também como trabalhador, em um relacional funcional. Essas relações não são exclusivas, mas se influenciam mutuamente e determinam forma e função dos produtos e instrumentos. A dimensão prática na relação sujeitoobjeto não apenas estabelece critérios de concepção diferenciados, conforme o tipo de agente (usabilidade, manufaturabilidade, manutenabilidade, reciclabilidade), como deve orientar a expressão das necessidades (em situações reais e de utilização efetivas, em contraposição a simulações e experimentos em laboratórios) e a metodologia de concepção (participação da perspectiva da atividade, a coprodução do serviço pelo usuário). Trata-se, nesse caso, de evidenciar as dificuldades postas pela natureza específica da esfera da prática, tais como a expressão de percepções e sensações corporais, intuições e experiências vivenciadas, o que exige a problematização na noção de "participação" e o desenvolvimento correlato de teorias da prática - ou, como 
preferem outros autores, teorias da ação e teorias da atividade, conforme, por exemplo, Chaiklin e Lave (Eds.) (1996), e da cognição situada (THEUREAU, 1992). Em relação à participação, dada a natureza tácita do saber prático e o caráter situado da ação, a explicitação de necessidades requer condições específicas, não acontecendo de forma espontânea. Não basta convidar as pessoas a falarem ou expressarem imediata e conscientemente suas demandas, como pretende a pesquisa de opinião ou o preceito de ouvir a "voz do cliente".

É nesse terceiro eixo que se situa a intervenção relatada neste artigo, com base na Metodologia de Análise Ergonômica do Trabalho (AET), que oferece recursos para uma concepção de postos de trabalho centrada na atividade e permite responder a questões ainda não resolvidas pelo projeto centrado no consumidor ou projeto centrado no usuário (user-centered design). Os dados apresentados resultam de análises da atividade e de validação das propostas em um projeto participativo junto aos trabalhadores e engenheiros da empresa, ao longo de oito meses. Antes de apresentar os resultados, são resumidos os princípios que definem a metodologia de análise centrada na atividade.

\section{MÉTODO: COMPREENDER A ATIVIDADE PARA ADEQUAR OS INSTRUMENTOS AOS USUÁRIOS}

\subsection{Análise ergonômica do trabalho}

A AET está bem formalizada em seus aspectos gerais e operacionais (GUÉRIN et al., 2002). Seu princípio fundamental consiste em evidenciar o "trabalho real" em contraste com a organização formal, explicitando o saber informal (savoir-faire, tacit skills) dos atores em situação, os critérios que orientam suas ações e os objetivos conflitantes que definem seus comportamentos no trabalho. Esse conhecimento só é acessível depois de longas observações e vivência ao lado dos atores em situações reais, isto é, no próprio contexto onde se realizam suas atividades cotidianas. A natureza desse savoir-faire requer metodologias qualitativas, que permitam avaliar as condições existentes numa determinada situação, que tanto favorecem quanto dificultam a ação. Fazem parte da situação tanto as condições objetivas como as subjetivas, ou seja, os meios e instrumentos materiais e organizacionais para se realizar as tarefas e as formas como elas são realmente realizadas pelos indivíduos (estratégias, conhecimentos, critérios de decisão, modos operatórios...).
De um lado, procura-se descrever a variabilidade da situação (técnica, organizacional e humana), de outro, explicitar como os atores sociais reagem às dificuldades e tentam superá-las em sua atividade cotidiana. O processo de análise sistemática das atividades é construído a partir da expressão verbal efetuada pelos atores a respeito de seu comportamento e das condições que afetam a realização de seu trabalho. Essas verbalizações podem ser espontâneas, mas geralmente são "provocadas" durante a realização da atividade (verbalização interruptiva) ou após sua consecução (verbalizações consecutivas), visando explicitar as razões, os meios e as finalidades das ações realizadas. 


\subsection{Processo participativo de desenvolvimento do projeto}

O desenvolvimento da bancada ocorreu de forma participativa, a partir de uma concepção inicial, elaborada com base no diagnóstico realizado. A proposta inicial foi validada pelas inspetoras em seus princípios gerais, mas a recomendação para aumentar a iluminação difusa da sala foi rejeitada, fato que se revelou pleno de significados. A baixa intensidade da iluminação ambiente em contraste com a forte intensidade das luminárias nos postos de inspeção podia estar relacionada com as frequentes dores de cabeça. Reduzir a diferença era inadmissível para as inspetoras, pois o contraste luminoso é fator preponderante na qualidade da inspeção das ampolas. Assim, foi preciso redimensionar a luminária, mantendo o iluminamento ambiente reduzido, como exigido pelas operadoras.

Após a análise da atividade, foi feito um primeiro esboço da bancada, orientado pelos resultados da observação sistemática da ação e do levantamento detalhado das estratégias desenvolvidas pelas inspetoras para superar as deficiências da bancada existente. A participação deles se deu, inicialmente, de forma coletiva, comentando o desenho da proposta e recomendações gerais como a iluminação da sala. Intervenções das inspetoras incorporadas ao projeto da bancada serão apresentadas no tópico específico sobre a evolução do protótipo.

A segunda fase de participação, agora individual, ocorreu durante os testes do protótipo em situação real, quando repetimos as observações sistemáticas, em dias e momentos distintos, definidos por meio da análise da variabilidade da produção e do tipo de produto que estaria sendo revisado pelas inspetoras. Durante o uso, fazíamos perguntas para estimular a verbalização, sem direcioná-las para características da bancada, interrompendo a realização da tarefa em momentos que a inspetora realizava uma determinada manobra com os frascos para revisá-los (retirar das bandejas, agitar o frasco, inspecionar sobre o fundo preto e branco e devolvê-los à bandeja de revisados). Durante os testes, eram feitos registros fotográficos e anotados os comentários das inspetoras.

Esse processo projetual difere do processo de tentativa e erro adotado pela empresa em alguns aspectos essenciais. No processo de tentativa e erro, não eram feitas avaliações sistemáticas, organizadas e planejadas da utilização das bancadas compradas ou dos protótipos desenvolvidos na própria empresa, especificados a partir de observações pontuais e limitadas a certos aspectos de desconforto (postura da coluna cervical, braços elevados etc.). As técnicas adotadas na AET para diagnóstico da carga de trabalho global, evidenciando componentes físicos, cognitivos e afetivos os suportes para favorecer a verbalização e a participação -, a diferenciam dos métodos de engenharia que, quanto à funcionalidade da bancada, se assemelhavam mais a um processo de tentativa e erro. Os parâmetros de decisão da empresa para avaliar a eficiência da bancada se resumiam ao rendimento do trabalho, indicado pela quantidade de ampolas revisadas. Os aspectos de saúde, conforto, qualidade da inspeção e eficácia não eram levados em conta, senão de modo isolado. Esses parâmetros quantitativos sumários revelam uma visão reducionista da atividade, desconectada de suas características mais relevantes, como o compromisso com a qualidade do trabalho.

O primeiro protótipo foi construído com ajustes suficientes para realizar uma bateria de testes conduzidos segundo critérios coerentes com a atividade. Como se dispunha de apenas uma bancada, foram definidos períodos de utilização para trabalhadores escolhidos de acordo com as seguintes características pessoais:

- altura com variação aproximada de $5 \mathrm{~cm}$, cobrindo todo o universo da população, pois as alturas eram muito próximas;

- tempo de experiência variável: menos de um ano, três anos, cinco anos e mais de cinco anos;

- homens e mulheres (a maioria dos trabalhadores eram mulheres; dois homens trabalhavam na área há menos de um ano).

Dependendo da disponibilidade, cada inspetora ficava na bancada até oito dias de trabalho efetivo, e o tamanho do grupo de testes variava entre quatro, cinco e seis pessoas, em um total de catorze do setor. Além do grupo de testes, todas as outras inspetoras foram convidados a usar a bancada por um período mínimo de quatro horas para que, nas reuniões de avaliação coletiva, pudessem opinar e sugerir modificações. Cada uma das modificações propostas era sistematicamente validada com o grupo.

\section{ESTUDO DE CASO: A INSPEÇÃO DE AMPOLAS}

A análise da atividade de inspeção exigiu uma análise cinesiológica refinada, inicialmente para demonstrar possíveis nexos entre modos de operação desenvolvidos pelas inspetoras e patologias e queixas de dores, não reconhecidas pelo Serviço Médico da empresa. Somente então é que o setor de engenharia foi convencido a desenvolver mais um projeto da bancada de inspeção.

\subsection{Análise cinesiológica da atividade de inspeção}

A análise cinesiológica é um estudo das posturas, movimentos, gestos e técnicas corporais adotados no trabalho. Os gestos podem ser relacionados às exigências da tarefa, 
aos resultados esperados pelos auxiliares de produção, às dificuldades encontradas para corresponder a tais resultados e ao acometimento de disfunções osteomusculares.

A tarefa de inspeção pode ser resumida em três etapas (Tabela 1). Dessas fases, predominam em termos de tempos e movimentos as duas primeiras, analisadas mais detalhadamente a seguir.

O trabalhador pega uma caixa com ampolas em um pallet próximo a sua bancada, senta-se e posiciona a caixa sobre seu colo (Figura 2).

Em seguida, em ciclos repetidos, pega várias ampolas e as posiciona em frente à placa para inspecionar a qualidade do bico (Figura 3). A quantidade de ampolas manipuladas depende de cada trabalhador; em média são inspecionadas oito ampolas de cada vez. A inspetora descarta as ampolas com bicos ruins colocando-as em um compartimento

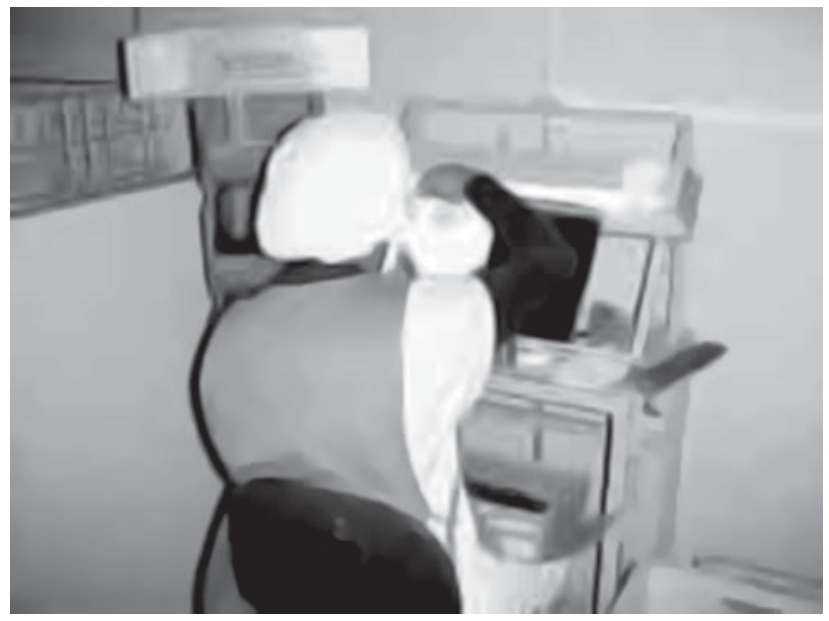

Figura 1: Posto de trabalho e postura típica da inspeção visual de ampolas.

Tabela 1: Etapas da tarefa de escolha de ampolas

\begin{tabular}{|c|c|}
\hline Etapa & Descrição \\
\hline $\begin{array}{l}\text { 1) Inspeção dos } \\
\text { bicos e limpeza }\end{array}$ & $\begin{array}{l}\text { Posiciona as ampolas nas mãos para inspecio- } \\
\text { nar os bicos, fazer limpeza externa e enxugar. } \\
\text { As ampolas descartadas são colocadas no } \\
\text { compartimento próprio (Figuras } 2 \text { e } 3 \text { ) }\end{array}$ \\
\hline $\begin{array}{l}\text { 2) Inspeção visual } \\
\text { sobre fundo preto/ } \\
\text { branco (placa de } \\
\text { contraste) }\end{array}$ & $\begin{array}{l}\text { Reposiciona as ampolas na mão (direita ou es- } \\
\text { querda dependendo da dominância) e faz ins- } \\
\text { peção do conteúdo contra a placa de contraste } \\
\text { (Figuras } 1,4 \text { e 5). } \\
\text { Nesta etapa os trabalhadores intercalam os } \\
\text { movimentos de agitar as ampolas e observar } \\
\text { contra a placa }\end{array}$ \\
\hline $\begin{array}{l}\text { 3) Armazenamen- } \\
\text { to de produtos } \\
\text { bons e refugos }\end{array}$ & $\begin{array}{l}\text { As ampolas descartadas são jogadas em com- } \\
\text { partimento próprio (Figura 6). } \\
\text { As ampolas aproveitáveis são posicionadas na } \\
\text { caixa menor, ao lado, e o trabalhador retorna as } \\
\text { mãos para a caixa que fica em seu colo para } \\
\text { reiniciar o ciclo de trabalho }\end{array}$ \\
\hline
\end{tabular}

específico, posicionado a sua esquerda ou a sua direita, dependendo de cada posto de trabalho (Figura 6). Na etapa 2, retoma as ampolas e as observa contra o fundo preto e depois o branco (ou vice-versa), verificando se existem partículas suspensas. Para isso, alterna os movimentos de agitar e observar contra a placa. O trabalho prescrito é agitar as ampolas apenas uma vez, mas os trabalhadores preferem agitar e observar as ampolas várias vezes, pois, como explicam, a responsabilidade é grande: são medicamentos que serão injetados em seres humanos.

As ampolas aprovadas são posicionadas em uma grade situada ao lado da bancada, as não aprovadas vão para uma caixa situada do mesmo lado das ampolas com os bicos ruins.

A quantidade de vezes que cada inspetora agita as ampolas e a duração da inspeção visual variam bastante entre

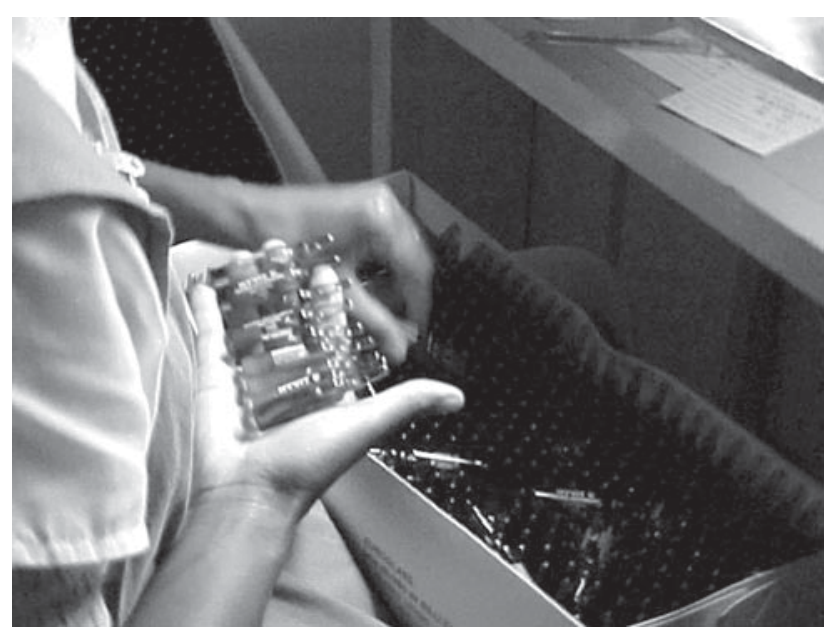

Figura 2: Caixa posicionada no colo, posicionamento das ampolas nas mãos.

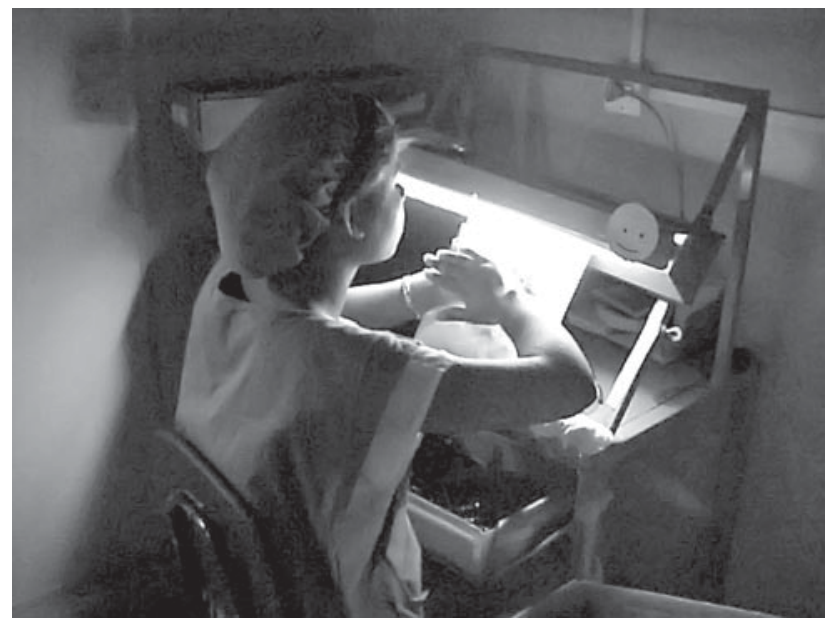

Figura 3: Observação dos bicos das ampolas contra a placa. 


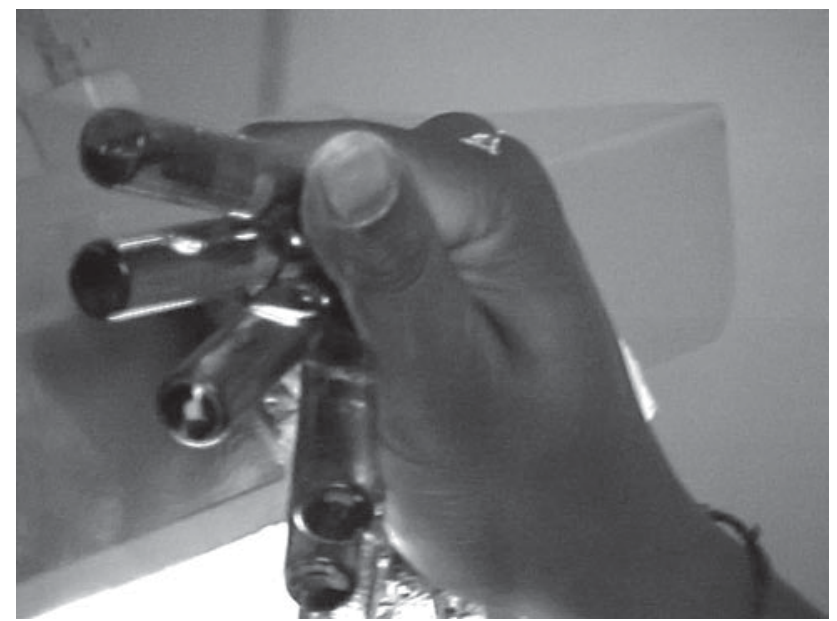

Figura 4: Inspeção do conteúdo das ampolas contra a luz.

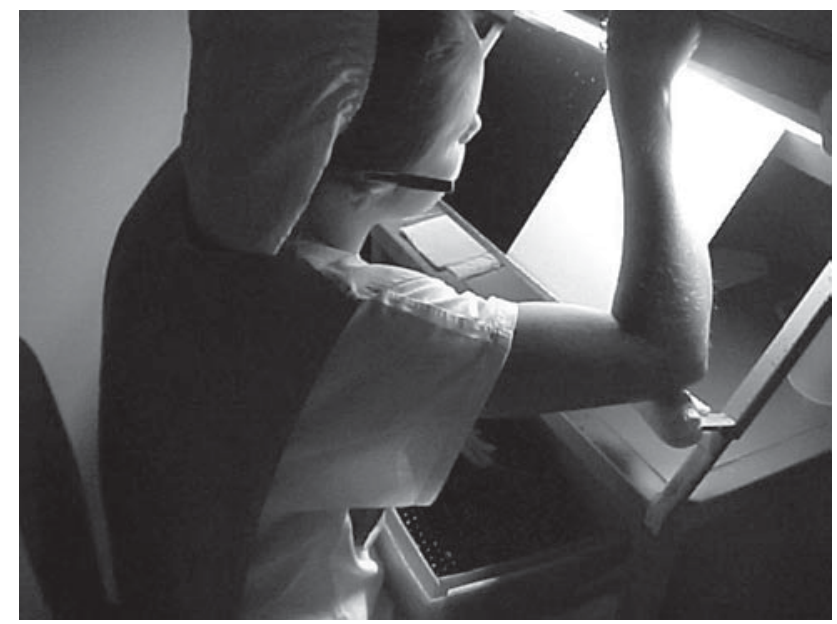

Figura 5: Inspeção do conteúdo das ampolas contra a luz.

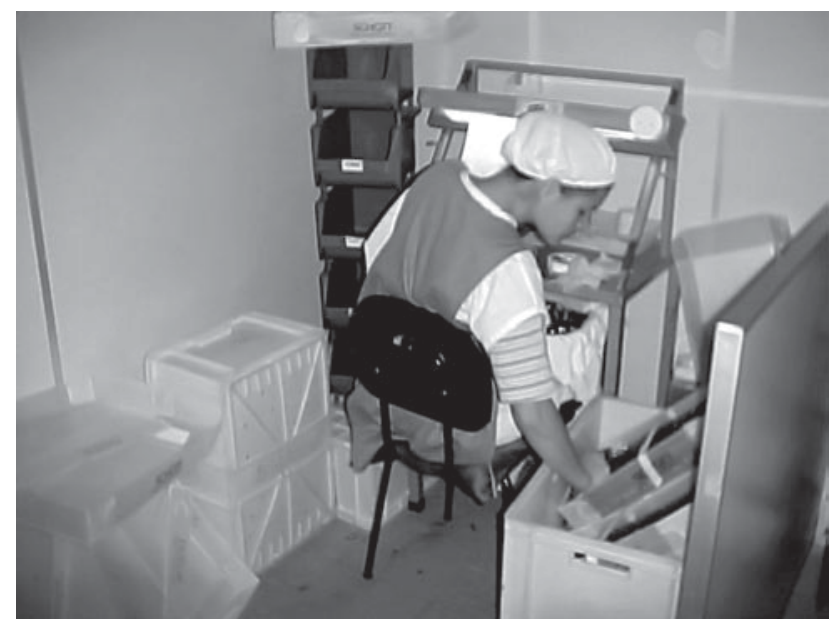

Figura 6: Vista geral do posto de trabalho: à esquerda, mais escuros, compartimentos para refugo, à direita, embalagem das ampolas aprovadas. elas e para uma mesma inspetora, dependendo dos produtos e das condições de qualidade (se os bicos das ampolas estão com mais ou menos defeitos, se o trabalhador acredita que pode haver maior risco de encontrarem partículas suspensas, ou mesmo pela acuidade visual de cada um). Para efeitos de avaliação da carga de trabalho, é possível definir indicadores mais sintéticos. Tomando como unidade o ciclo completo, as inspetoras permanecem até $60 \%$ do tempo com o ombro direito em flexão, com abdução e rotação interna (Figuras 3 a 6). Essa postura pode variar conforme o modo operatório de cada inspetora, além da diferença entre destros e canhotos.

Algumas inspetoras apoiam a mão sobre a placa, outros não. Na Figura 5 é possível observar uma inspetora apoiando o cotovelo direito na bancada, cuja aresta viva foi envolvida em gaze. Essa postura está relacionada a patologias diversas: tendinite do supraespinhoso, tendinite da porção longa do bíceps, síndrome do impacto (HAGBERG et al., 1995; MAGEE, 2002), nexo que, nesse trabalho, é corroborado pelas prevalências de dor no ombro, conforme dados dos prontuários médicos e dos questionários. Das catorze inspetoras do setor, doze apresentavam queixas recidivas de dores nos ombros, com afastamentos e exames de ultrassonografia indicando lesões avançadas (inclusive rupturas parciais) no tendão do supraespinhoso, principal músculo atuante na abdução. Queixas recorrentes ocorriam devido à recusa da médica do trabalho em reconhecer o nexo entre as dores e o trabalho de inspeção.

Além da exigência sobre o ombro, uma sobrecarga importante decorre da flexão dos dedos para segurar e agitar as ampolas, intensificada quando as ampolas estão molhadas, pois é necessário aumentar a força de preensão. Nesse caso, os riscos de lesão possíveis são Tenossinovites dos músculos flexores dos dedos, Epicondilite Lateral ou Medial, e Síndrome do Túnel Radial (COELHO; REIS, 1998). Como

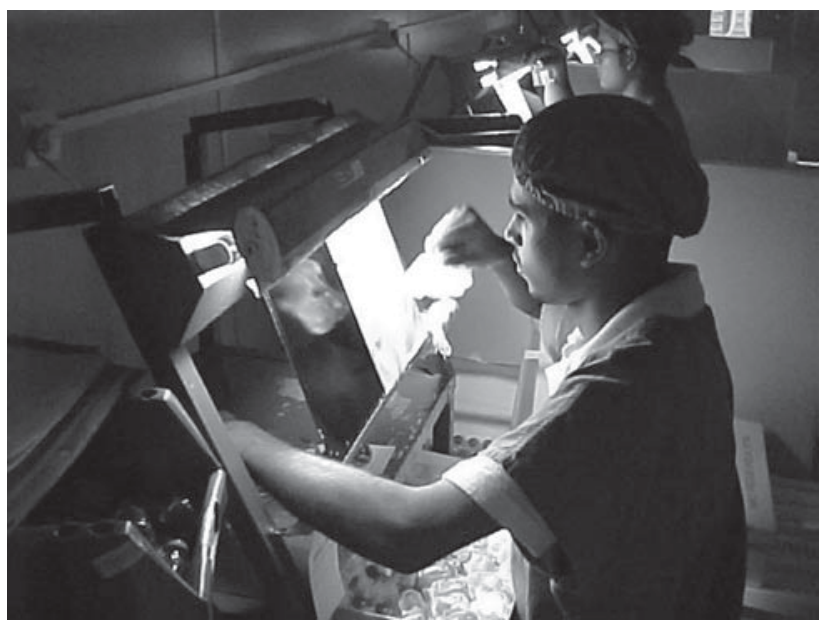

Figura 7: Apoio do antebraço em aresta viva. 
os movimentos de desvio ulnar ou radial dependem do modo operatório, é possível que algumas inspetoras apresentem patologias mais específicas no punho.

Esta análise permitiu explicar queixas de dores no punho não utilizado diretamente na manipulação das ampolas, evidenciadas nos questionários e nos prontuários. Várias inspetoras do setor apoiavam o punho ou o antebraço em uma aresta viva da bancada enquanto inspecionavam as ampolas (Figura 7). Essa característica poderia não ter sido evidenciada e devidamente ponderada se não fosse a participação das inspetoras no processo de investigação e no cruzamento dos dados com os prontuários médicos, que indicavam dores na região do punho esquerdo.

Além das patologias (MAGEE, 2002) associadas à manutenção da postura sentada por longos períodos de tempo (na inspeção, as inspetoras se levantam apenas para registrar caixas com ampolas revi-

sadas e pegar novas caixas e, eventualmente, para secar as ampolas), para revisar as ampolas, as trabalhadoras precisam se aproximar da placa de contraste (Figura 5). Além de agravar o risco de dores lombares, devido à diminuição da lordose e da não utilização do apoio da cadeira, podese observar também que algumas inspetoras realizam uma protusão da cabeça (postura com a cabeça para frente), o que pode causar dores na coluna cervical e na torácica.

O posicionamento das caixas com ampolas no colo pode causar dores na coluna lombar e nos membros inferiores, edemas nos tornozelos e pés, devido à impossibilidade de alterar a postura durante a realização da atividade. No entanto, como será discutido adiante, os trabalhadores preferiram continuar com as ampolas no colo a usar um dispositivo para apoiar a caixa.

A análise cinesiológica descreve como as pessoas trabalham e permite compreender "por que trabalham dessa forma". Para isso, as técnicas corporais devem ser relacionadas a outros aspectos do trabalho de inspeção. É possível relacionar gestos e posturas a dores osteomusculares que podem acometer os sujeitos, entendendo os determinantes da atividade e seus constrangimentos, elementos que devem ser considerados no reprojeto do posto de trabalho.

\subsection{Os condicionantes sociais da inspeção}

Ainda que esta descrição cinesiológica seja necessária para entender os mecanismos fisiológicos que geram dores e adoecimentos diversos, não há uma relação direta entre esses padrões de movimento e a carga de trabalho a que se submetem as inspetoras. Entre os movimentos e o uso do corpo, interpõem-se relações sociais que explicam por que esses padrões surgem, nem sempre evidenciadas em análises biomecânicas clássicas (NAVEIRO; GUIMARÃES, 2003). Enquanto gestos humanos e usos sociais do corpo, esses padrões não são puramente fisiológicos, mas se definem também por normas e valores sociais. A não compreensão da imbricação entre padrões fisiológicos e normas e valores sociais que dão forma a esses padrões levou a sucessivos fracassos de reprojeto da bancada de inspeção.

Uma norma social diz respeito aos gestos que precedem o gesto de pegar as ampolas. As inspetoras mantêm pedaços de tecido para secar as ampolas. Quando chegam úmidas, 

lhadoras desenvolvem, e que lhes são caros. No entanto, por serem subjetivos, não quer dizer que possam ser mudados como se fossem simples manias ou maus hábitos. Ao contrário, as inspetoras estão tão fortemente impregnadas desses cuidados com os outros que esses valores têm força objetiva, mandatória: não podem fazer de outro jeito e o corpo se comporta como uma máquina que introjetou essas normas sociais, tal qual uma camisa de força que inibe os movimentos. Apesar de imateriais e subjetivos, esses valores, como os constrangimentos de uma bancada mal projetada, determinam os gestos repetidos das inspetoras.

\section{O PROJETO DA BANCADA}

A análise de postos de trabalho, de uma perspectiva ergonômica, não pode se resumir a uma descrição física inadequadas, parte devido a valores que as próprias traba-

Essa descrição geral é que tem servido de princípio para a concepção dos postos de trabalho que buscam, sobretudo (e quase unicamente), fornecer o contraste de cor e de iluminação. Todavia, como essa descrição genérica da tarefa é insuficiente para dar conta do conteúdo fisiológico, cognitivo e afetivo do trabalho de inspeção, alguns aspectos essenciais da atividade acabam sendo negligenciados, fazendo com que os projetos sejam recusados pelas inspetoras.

\subsection{Tentativas fracassadas de melhoria da bancada}

As tentativas anteriores de melhoria do posto de trabalho foram devidamente documentadas, mas deixaram traços suficientes para se entender por que não foram validadas pelas operadoras. Uma primeira tentativa foi com bancadas construídas nas oficinas da empresa, sob orientação de um engenheiro bastante motivado, mas sem qualificação em ergonomia para entender a complexidade da atividade. Segundo relato das inspetoras, os projetos "apareciam" de repente para serem testados em situação de produção, algumas vezes as bancadas já eram instaladas

do ambiente, levada a termo de forma isolada da atividade de quem trabalha. No caso da atividade da inspetora, observa-se a articulação dos aspectos objetivos da tarefa e sua inserção no fluxo de uma atividade significativa, que inclui a presença de outro genérico que vai receber uma injeção, em tempo e lugar ainda indefinidos. A fim de justificar essa abordagem que considera a dinâmica da atividade em um contexto social mais amplo, faremos uma descrição geral da bancada de escolha e das diversas tentativas, malsucedidas, de sua substituição. A avaliação crítica dessas tentativas evidenciará os princípios genéricos assumidos para especificar esse posto de trabalho, insuficientes para orientar o redesenho ergonômico da bancada.

Como comentado, o objetivo essencial da tarefa de inspeção consiste em separar ampolas boas e ruins, observando características visuais internas (partículas em suspensão, impurezas, pedaços de vidro, volume...) e externas (qualidade da impressão da identificação do produto, conformação do bico da ampola). A visualização dos problemas de qualidade é facilitada pela placa de contraste de cor (fundo preto e branco) e de intensidade luminosa (iluminação local $\times$ ambiente). Para conseguir boas condições de visualização, as ampolas devem ser agitadas e mantidas a uma pequena distância dos olhos. Assim, o posto de trabalho deve ser, de início, uma bancada que permita a visualização de pequenos detalhes através de contraste de cor e de iluminação. em grande quantidade, havendo casos de uma rejeição unânime por parte das inspetoras. Paralelo a essa rejeição, sucediam-se outras tentativas inócuas de adaptações das bancadas às necessidades do trabalho, cujos requisitos não eram suficientemente compreendidos e explicitados.

Uma das bancadas consistia em tornar a luminária ajustável, apoiando-a em uma haste flexível que permitia redirecionar a iluminação local, diminuindo um fator de rigidez postural e permitindo eliminar reflexos sobre a placa do contraste. No entanto, com esse dispositivo, que trazia algumas vantagens, as inspetoras perdiam o apoio para a mão durante a visualização das ampolas, micropausa que alivia a carga de sustentação do braço.

Outra tentativa foi adquirir um dispositivo fornecido por uma empresa especializada em equipamentos de inspeção de qualidade. Esta bancada consistia em um quadro de visualização de chapas de radiografia, como as usadas em clínicas médicas, montadas em uma superfície plana, como se fosse uma mesa, semelhante a uma fotocopiadora. Essa bancada tem a vantagem de aliviar a carga postural de sustentação dos braços, pois a inspeção visual é feita olhando o produto de cima para baixo, com as ampolas em posição horizontal e não mais na vertical. Esqueceu-se, porém, que o alívio dos ombros e braços trouxe sobrecarga para a coluna, pois essa bancada implica exigências de flexão cervical quase permanente. Em 
termos de economia global do corpo, não houve ganho para as inspetoras.

Após cada mudança, quando se percebia queda na produção, as bancadas eram substituídas pelas antigas e outra tentativa era iniciada. Fruto dessas tentativas e erros, considerada pelas operadoras inclusive como o resultado final, foi a bancada que encontramos ao iniciar este trabalho.

\subsection{A bancada existente}

A Figura 1 mostra a bancada existente, com várias inadequações ergonômicas, mas bem aceita pelas operadoras devido às experiências negativas anteriores. Nas condições existentes, a atividade de inspeção, para atender exigências de qualidade e de produção, era realizada com padrões de movimentos que traziam sobrecarga física, sobretudo de ombros e membros superiores. O redesenho do posto de trabalho deveria, assim, corrigir as seguintes inadequações da situação de trabalho existente:

- pouco espaço nas laterais para manipular as embalagens e ampolas para revisar e revisadas;

- espaço exíguo para as pernas, dificultando alternância de postura e impedindo o giro do corpo, o que levava à torção do tronco;

- a iluminação precisava ser melhorada, de modo a possibilitar regulagens em diferentes situações, variando contraste e luminosidade;

- a bancada não oferecia apoios para braços e mãos em todas as fases de trabalho, sobretudo durante a inspeção visual propriamente dita;

- a bancada apresentava limitações quanto à possibilidade de adaptação às características pessoais, o que levava os trabalhadores a improvisarem dispositivos de regulagem e de organização do posto. Parte dessas improvisações serviu de ponto de partida para o reprojeto da bancada de escolha, mas nem sempre os operadores conseguem adotar modos de operação satisfatórios quanto aos aspectos ergonômicos, o que pode mais cedo ou mais tarde comprometer sua saúde.

Retomando de maneira mais detalhada e sistemática a análise do posto de trabalho, foram evidenciadas dificuldades bem características, que orientaram o processo de projeto:

- as diversas improvisações sugeriam, no redesenho do posto de trabalho, a necessidade de se adotar uma visão global, fundada na análise sistêmica da atividade de inspeção;

- presença de vários objetos pelo chão, reduzindo o espaço e dificultando a realização de movimentos essenciais para a atividade, repetidos várias vezes durante a jornada de trabalho;
- pequenas caixas de ampolas/frascos acondicionados sobre as pernas, restringindo mais ainda a movimentação e mudança de postura;

- a inexistência de apoios para os cotovelos, levando a posições extremas do punho para posicionar a ampola diante do contraste, que por sua vez não dispunha de regulagens de altura e inclinação;

- improvisando um apoio, os trabalhadores envolviam o perfil metálico de sustentação do contraste com gaze para eliminar a aresta viva. Porém, quando o frasco precisava ser revisado no contraste à esquerda (preto ou branco, conforme o modo operatório do operador), o apoio improvisado deixava de ser útil: o braço esquerdo era apoiado em uma parte do perfil (uma fresta) logo abaixo do contraste e o cotovelo se apoiava sobre o braço;

- o brilho da pintura provocava reflexos, aumentando a luminosidade incidente sobre os olhos, já intensa devido ao contraste entre iluminação ambiente e o foco de luz;

- o material branco do contraste se degradava com luz e calor, ficando com tonalidade amarelada, sendo necessário, mais uma vez, improvisar, cobrindo o contraste com folhas de papel branco.

\subsection{Projeto de uma nova bancada}

O conceito da proposta de posto de trabalho da escolha buscou um espaço de trabalho flexível, ajustável ao biótipo do operador e à variação do modo operatório. $\mathrm{O}$ conceito foi desenvolvido com base nas observações da atividade, nos comentários e sugestões das próprias inspetoras e da análise das improvisações e estratégias desenvolvidas para superar as deficiências da bancada existente. Uma primeira idéia foi apresentada aos trabalhadores e enriquecida com as sugestões que passaram pelos critérios técnicos e de custo postos pela empresa. Algumas sugestões não foram incorporadas ao projeto devido a limitações dos equipamentos disponíveis na oficina para fabricar os mecanismos mais aperfeiçoados para as regulagens da bancada, da luminária e dos apoios de braço. Os trabalhadores preferiam regulagens contínuas (com parafusos sem fim e cremalheiras), de fácil manipulação e que permitem ajustes mais finos. Revestir a parte superior da bancada com borracha antiimpacto foi considerado de custo elevado pela empresa.

Após essa primeira validação, o projeto conceitual do posto de trabalho definiu-se pelas seguintes características:

- bancada que funcione como suporte para acomodar os artefatos necessários à tarefa, sem pés, a fim de permitir livre movimentação das pernas; 
- luminária com movimentos giratórios para direcionar a intensidade da iluminação, com inclinação para que as pessoas possam executar a tarefa à altura dos olhos, como fazem atualmente, e mantendo os braços apoiados, o que não acontece na bancada existente;

- além da bancada, integrar suporte para caixas de frascos, liberando o espaço de movimentação das pernas;

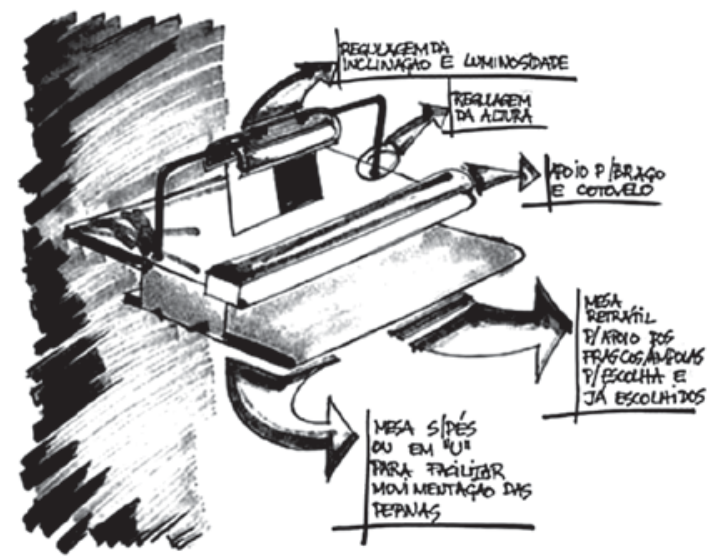

Figura 8: Croqui para desenvolver o primeiro protótipo.
- suporte retrátil para apoio da bandeja de ampolas, atualmente apoiada sobre as pernas;

- posição das cores (preto e branco) do contraste variável;

- contraste ajustável, sem apoio sobre a bancada, facilitando a limpeza de resíduos de ampolas quebradas.

Limitações técnicas e de custo postas pela empresa para execução do projeto - os componentes da bancada e a

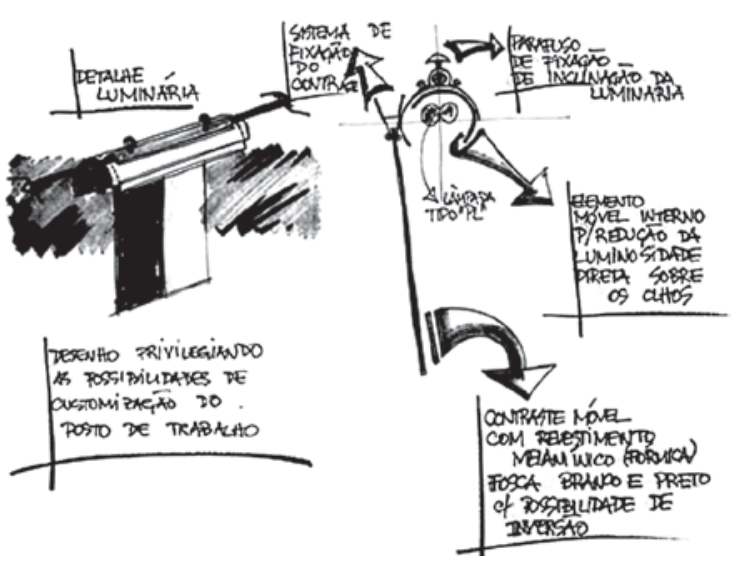

Figura 9: Croqui da luminária.

Tabela 2: Características do projeto conceitual apresentado aos trabalhadores.

\begin{tabular}{ll}
\hline \multicolumn{1}{c}{ Característica } & \multicolumn{1}{c}{ Origem } \\
\hline Luminária - regulagem do foco de luz & $\begin{array}{l}\text { Fita adesiva adaptada pelos operadores, utili } \\
\text { zada como uma espécie de aba para regula } \\
\text { luminosidade }\end{array}$ \\
$\begin{array}{l}\text { Inversão do contraste - } \\
\text { preto/branco e branco/preto }\end{array}$ & $\begin{array}{l}\text { Papéis eram colados sobre o contraste para } \\
\text { rantir esta variação de posição }\end{array}$ \\
$\begin{array}{l}\text { Regulagem de altura e profundidade da } \\
\text { luminária }\end{array}$ & Variação de altura e alcance dos operadores
\end{tabular}
luminária

Regulagem de altura e profundidade do apoio de braço e eliminação das arestas cortantes utilizadas como apoio

Regulação de altura da bancada

Mais espaço para os membros inferiores

Apoio retrátil para as bandejas
Variação de altura e alcance, e o fato de muitos operadores usarem o antebraço como apoio complementar para o cotovelo. As gazes enroladas no perfil da luminária eram utilizadas para reduzir o efeito negativo das arestas

Diferenças de altura dos operadores - uso de almofadas nos assentos das cadeiras

Observado o confinamento das pernas numa atividade que exige a rotação do tronco com frequência, mantendo as pernas na mesma posição

Observação da atividade e uso da bandeja
Justificativa

Reduz a incidência de luz diretamente nos olhos

A identificação dos possíveis contaminantes nos frascos é facilitada passando primeiro pelo contraste mais indicado para cada produto

Deixa o posto de trabalho mais flexível, ajustável às variações de biótipo e permite melhorar a acuidade visual aproximando mais os frascos do contraste. Reduz flexões e abduções do braço

Deixa o posto de trabalho mais flexível, ajustável às possíveis variações de biótipo e permite melhorar a acuidade visual aproximando mais os frascos do contraste. Diminui a compressão de punho e antebraço. Reduz flexões e abduções do braço

Reduz a possibilidade de dores nos ombros, coluna cervical e lombar

Deixa o corpo mais livre e permite reduzir as torções de tronco

Reduz o uso das pernas como apoio e dá mais liberdade de movimentação dos membros inferiores 
montagem deveriam ser realizados internamente - dificultaram a adoção das melhores soluções aos problemas identificados. As instalações eram precárias, com ferramentas de serralheria, impossibilitando trabalhos com madeira. Essa situação condicionou o desenvolvimento das propostas, conforme será discutido a seguir, elaboradas a partir dos esboços mostrados nas Figuras 8 e 9. O desenvolvimento do protótipo é relatado a seguir, apresentando as versões modificadas pelo processo interativo de teste e validação com as inspetoras. As soluções dadas aos princípios do processo projetual estão resumidas nas Tabela 2 , ressaltando a origem das modificações e justificativa.

\section{HISTÓRICO DO PROTÓTIPO}

Estes croquis, após validação pelos trabalhadores, foram os primeiros desenhos apresentados à empresa, com base nos quais foi desenvolvido o primeiro protótipo, construído internamente.

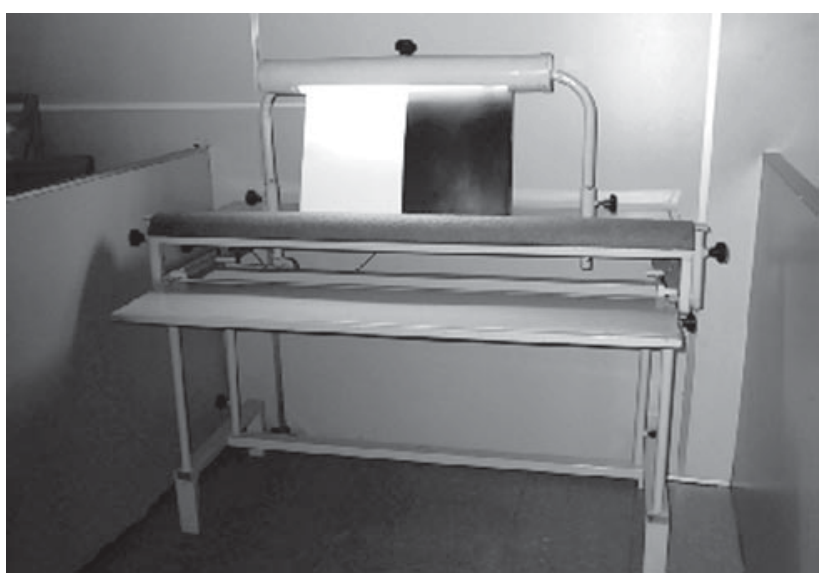

Figura 10: Vista geral do protótipo I.

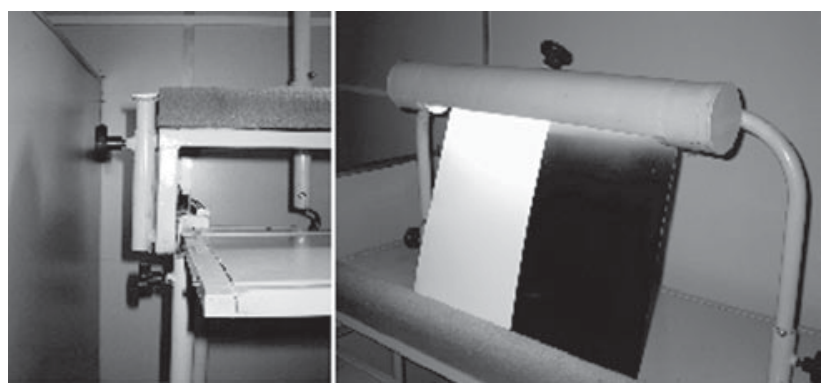

Figuras 11 e 12: Detalhes das regulagens do apoio de braço e da luminária

\subsection{Protótipo I}

Devido às limitações das oficinas, o protótipo não incorporou algumas características do projeto conceitual; entretanto, para uma fase de testes, a bancada construída (Figura 10) apresentava as funcionalidades mínimas, identificadas na análise e sugeridas pelos trabalhadores, conforme representadas nos croquis das Figuras 8 e 9. Somente depois de realizados os testes conforme os procedimentos comentados anteriormente é que seria iniciada a construção da bancada definitiva, com todas as funcionalidades previstas no projeto conceitual. As fotos das Figuras 10 a 12 mostram o protótipo e detalhes da luminária, ressaltando as possibilidades de regulagem da intensidade luminosa incidente sobre os olhos, a inclinação do contraste e as regulagens para o apoio do braço.

Neste protótipo foram acrescentados pés para sustentar o peso da mesa feita em metal. No projeto conceitual, a sugestão é que, na bancada final, fossem utilizados materiais mais leves (madeira e plásticos), permitindo apoiar a bancada nas divisórias que separam os postos de trabalho, ou usar modelos de pés que preservassem o espaço inferior da mesa para movimentação das pernas.

\subsection{Protótipo II}

Neste segundo protótipo, evoluiu-se para uma mesa com um recorte arredondado (Figuras 13 e 14 e Tabela 3), permitindo maior aproximação da mesa de trabalho e da luminária. Com mais proximidade, seria possível adotar uma postura em relação à mesa que permitiria o apoio dos cotovelos durante a fase de inspeção visual, o que não se passou com a mesa anterior em função da borda reta, avaliada como um empecilho para a realização da tarefa.

Ainda restavam acertos a serem feitos em relação à qualidade do acabamento da mesa e da luminária. Quando o projeto da bancada foi considerado satisfatório, sugeriu-se a contratação de um profissional especializado para construir mais um protótipo de testes (terceiro modelo), desta

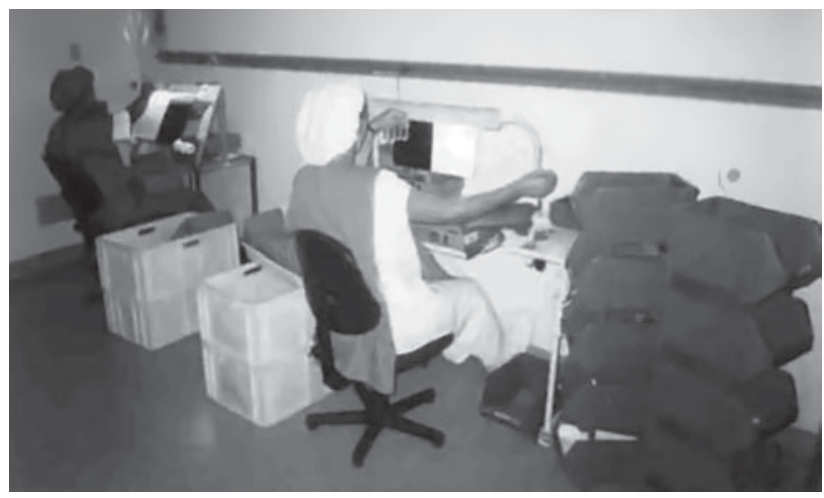

Figura 13: Visão geral do protótipo II. 
Tabela 3: Síntese das mudanças do protótipo I para o protótipo II.

\begin{tabular}{|c|c|c|}
\hline Característica & Intervenção/Mudança & Justificativa \\
\hline Superfície da mesa e pés & $\begin{array}{l}\text { Deixa de ser retangular e passa a ter a parte } \\
\text { central em formato de meia lua - por sugestão } \\
\text { dos operadores. } \\
\text { Os pés permanecem, pois a empresa decidiu } \\
\text { não investir em materiais diferentes }\end{array}$ & $\begin{array}{l}\text { Permitir maior aproximação do contraste, o } \\
\text { que não era facilitado pelas outras regula- } \\
\text { gens. } \\
\text { Essa intervenção foi inspirada nas mesas de } \\
\text { computador }\end{array}$ \\
\hline Apoio para o braço & $\begin{array}{l}\text { Passa a ser bipartido e com giro - sugestão } \\
\text { dos trabalhadores }\end{array}$ & $\begin{array}{l}\text { Gera espaço na superfície da bancada para } \\
\text { alocar a bandeja em uso, se necessário. Fa- } \\
\text { cilita a regulagem da profundidade e dá mais } \\
\text { flexibilidade às manobras de apoio de braço } \\
\text { e cotovelo. }\end{array}$ \\
\hline Apoio inferior para bandejas & Retirado - por sugestão dos trabalhadores & $\begin{array}{l}\text { Gerou insegurança na execução da atividade } \\
\text { e eles posicionavam a bandeja em uma altura } \\
\text { mais adequada para manipulação dos frascos, } \\
\text { além da inclinação das pernas facilitar a reti- } \\
\text { rada dos frascos a serem revisados }\end{array}$ \\
\hline
\end{tabular}

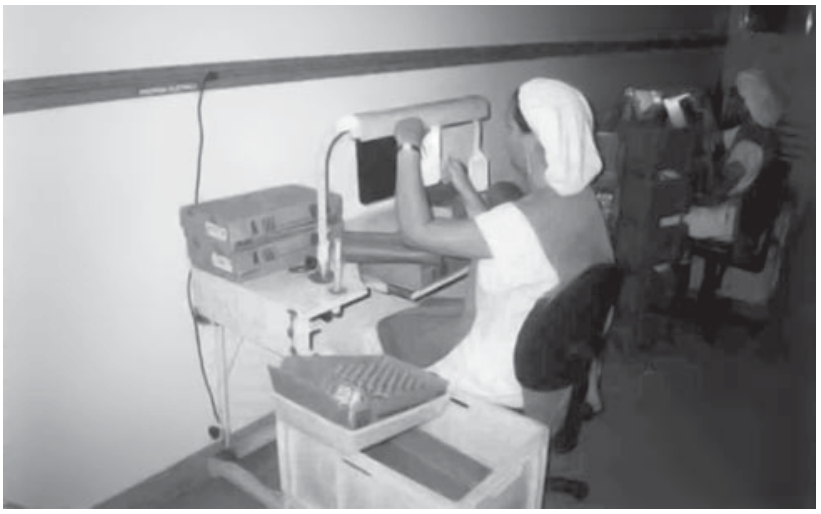

Figura 14: Protótipo II em detalhe.

vez procurando um acabamento mais definitivo. Diante da satisfação das inspetoras com o andamento dos testes, a empresa aprovou nossa sugestão e contratou um profissional externo, uma vez que, com os equipamentos disponíveis em suas oficinas, não seria possível obter um protótipo com acabamento melhor.

\subsection{Protótipo III}

O terceiro protótipo (Figuras 15 e 16), realizado pelo engenheiro indicado pela nossa equipe, foi muito bem avaliado pela equipe da escolha dos itens relativos ao acabamento, objetivo principal da contratação de um especialista externo à empresa. Entretanto, a funcionalidade ficou comprometida, sobretudo devido a alterações da luminária, cuja concepção se afastou das necessidades da tarefa. Apesar do avanço em termos de acabamento e estética, a luminária apresenta deficiências que inviabilizam seu uso quando considerados os modos operatórios reais,

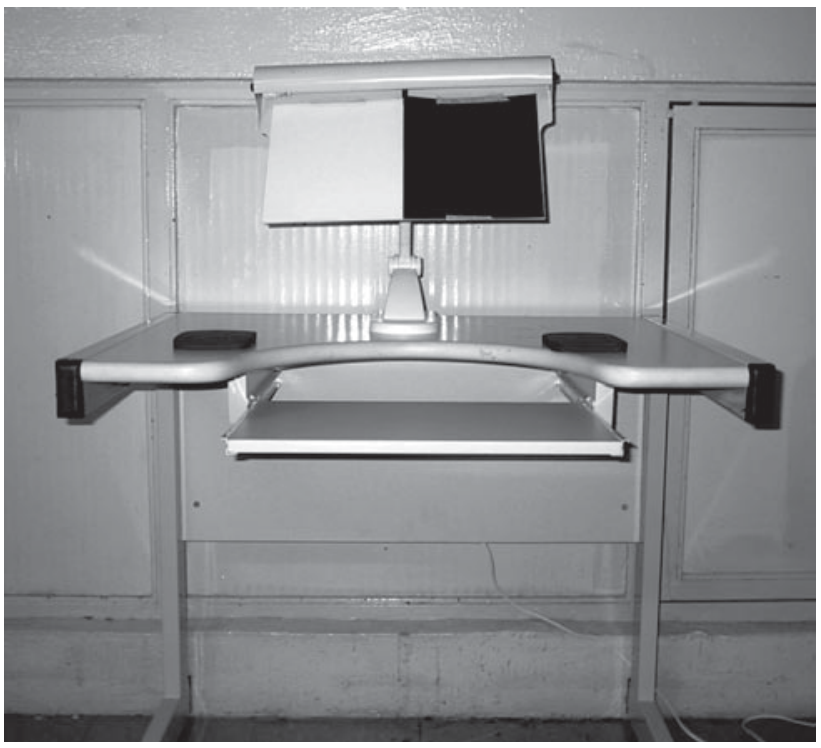

Figura 15: Vista geral do protótipo III.

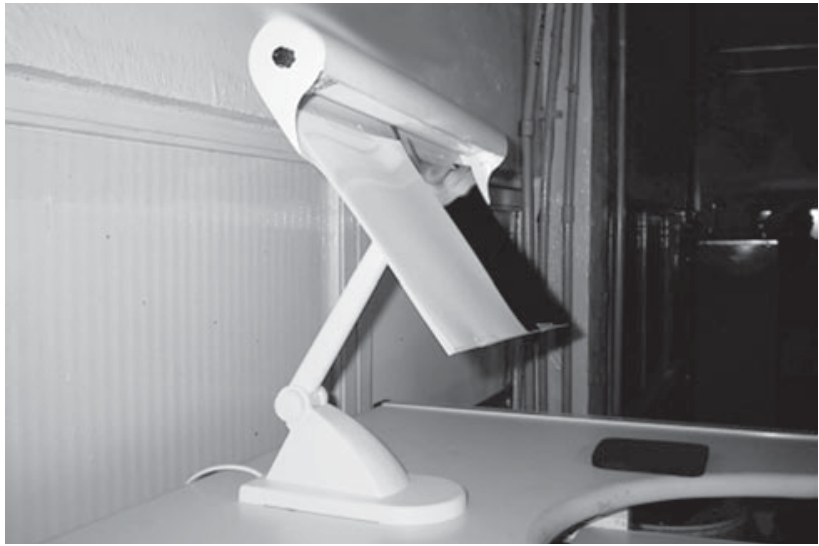

Figura 16: Detalhe luminária. 
pelas seguintes razões: (1) sua estrutura é muito leve, não oferecendo resistência suficiente para que os operadores se apoiem, fazendo micropausas durante a inspeção das ampolas; (2) sua base não está presa à mesa, o que a torna instável diante da movimentação de caixas e embalagens; e (3) não apresenta todas as regulagens de altura necessárias para ajustar o plano de trabalho.

Mesmo contando com serviços especializados para construir a bancada, ocorreu que o profissional contratado não conseguiu compreender os compromissos assumidos pelas inspetoras na realização da sua atividade e negligenciou pontos do projeto inegociáveis para os usuários, como trabalhar o mais próximo possível da fonte de iluminação, para garantir a identificação de pequenas contaminações nas ampolas. O retrocesso aconteceu porque esse novo ator interpretou o posto de trabalho como se fosse uma bancada semelhante à de um computador, perdendo as especificidades do trabalho de inspeção de ampolas. Entendendo que teria sido contratado para melhorar o projeto, ignorou as especificações e desenhos entregues, passando a interagir diretamente com o pessoal da administração da empresa sem se comunicar com nossa equipe, que não foi avisada sobre o contrato já estar em andamento.

\subsection{Protótipo IV}

Com a rejeição do protótipo III, e resultando de todo o processo de evolução com os testes de protótipos anteriores, implantados e acompanhados no dia a dia dos operadores, este último projeto é uma mescla de todos os outros, enriquecido das contribuições das inspetoras. Esse último protótipo, que seguramente não será o último, reúne elementos que o tornam melhor do que a bancada existente,

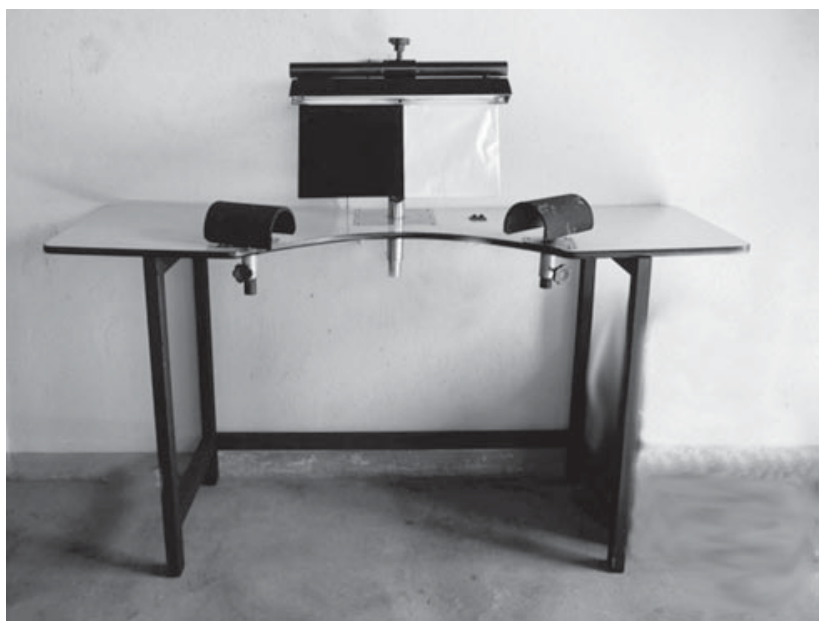

Figura 17: Vista geral do protótipo IV.

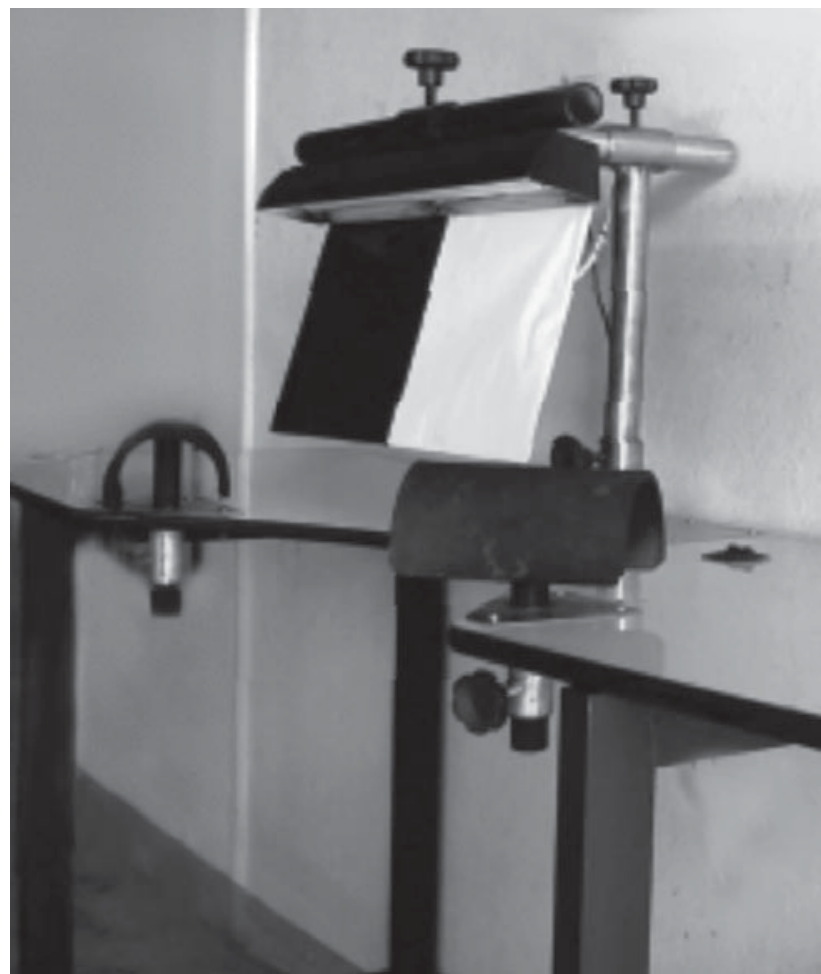

Figura 18: Detalhe da luminária.

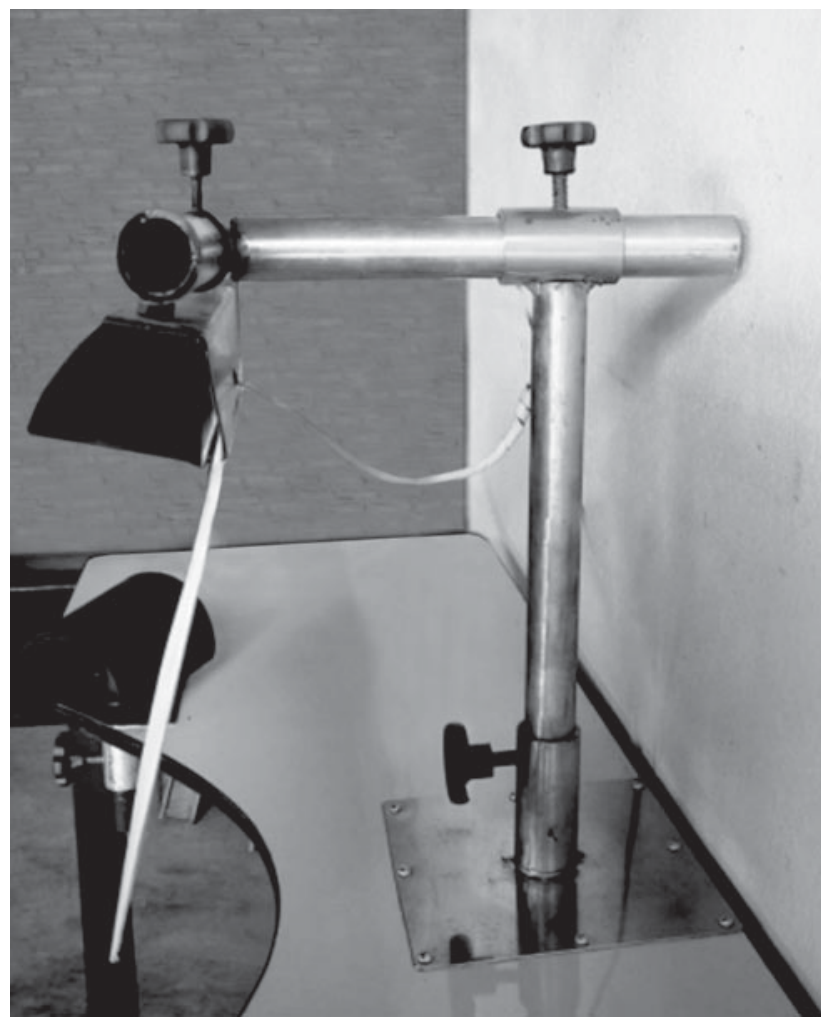

Figura 19: Vista lateral da luminária. 
Tabela 4: Comparação entre situação inicial e final - características principais.

\begin{tabular}{|c|c|c|}
\hline Característica & Bancada existente / Situação inicial & Protótipo IV / Situação final \\
\hline $\begin{array}{l}\text { Luminária - regulagem de altura, profundi- } \\
\text { dade e redução da luminosidade direta nos } \\
\text { olhos e robustez }\end{array}$ & $\begin{array}{l}\text { Não possui nenhuma dessas regulagens, mas } \\
\text { era robusta o suficiente para servir de apoio } \\
\text { para a mão (conforme modo operatório) }\end{array}$ & $\begin{array}{l}\text { Possui todas as regulagens e resistência para } \\
\text { apoiar a mão }\end{array}$ \\
\hline $\begin{array}{l}\text { Mesa - espaço para as pernas e aproximação } \\
\text { da luminária }\end{array}$ & $\begin{array}{l}\text { Espaço mínimo para as pernas e não permitia } \\
\text { aproximação da luminária de forma satisfató- } \\
\text { ria para aumentar a acuidade visual }\end{array}$ & $\begin{array}{l}\text { Maior espaço para as pernas, apesar de manter } \\
\text { os pés diferentemente do projeto conceitual. } \\
O \text { recorte na superfície oferece mais uma fa- } \\
\text { cilidade para que o operador se aproxime da } \\
\text { luminária }\end{array}$ \\
\hline $\begin{array}{l}\text { Apoio para os braços/cotovelos com regula- } \\
\text { gem de altura e profundidade }\end{array}$ & $\begin{array}{l}\text { Não possui regulagens. } \\
\text { Arestas são cortantes }\end{array}$ & $\begin{array}{l}\text { Possui as duas regulagens. } \\
\text { As arestas cortantes foram eliminadas }\end{array}$ \\
\hline $\begin{array}{l}\text { Variação de posição do contraste - branco/ } \\
\text { preto preto/branco ou somente branco ou } \\
\text { preto }\end{array}$ & Não possui & $\begin{array}{l}\text { Oferece a possibilidade de inversão e também } \\
\text { de ter contraste com apenas uma cor, branco } \\
\text { ou preto }\end{array}$ \\
\hline
\end{tabular}

considerada insubstituível até então, como se pode ver no resumo comparativo da Tabela 4 .

As fotos das figuras seguintes (17 a 19) são do último protótipo em que culminou essa série de testes e retratam a bancada de escolha que atualmente está sendo utilizada no trabalho de revisão dos frascos e ampolas.

Nesta última versão, já com um melhor acabamento, negociamos com a empresa o acompanhamento da execução, para evitar retrocessos em funcionalidades essenciais e já validadas. A versão IV incorpora de forma definitiva a madeira em sua estrutura e agrega funções antigas e melhoradas em relação às versões anteriores, como o suporte do conjunto luminária/contraste, projetado com apenas um ponto de apoio. Fabricada agora em maiores quantidades, está sendo usada rotineiramente de forma monitorada, para fazer adaptações que porventura ainda sejam necessárias. Um dos pontos críticos revelados pela análise foi a rigidez postural dos membros inferiores, em razão da falta de espaço sob a bancada e da bandeja apoiada no colo. O apoio retrátil ofereceria uma alternativa ao uso do corpo como suporte, o que deixaria as pernas livres de qualquer restrição. No entanto, as inspetoras jamais aceitaram esse dispositivo, considerando-o desconfortável e um empecilho para manter o ritmo de produção anterior. Após recusa tanto do apoio fixo quanto do móvel, que permaneceu sem ser utilizado, percebemos quanto esse apoio era disfuncional em relação aos gestos realizados próximos ao colo, que oferece uma zona de conforto máximo para os padrões de movimentos da primeira etapa de enxugar e pegar as ampolas. É inevitável a lembrança de várias tarefas domésticas e artesanais (como tricô, crochê e rendas de bilros) que envolvem padrões semelhantes de movimentos.

\section{CONCLUSÃO}

Um dos resultados indiretos desse processo participativo é que a empresa ganhou mais autonomia para criar postos de trabalho dentro dos pressupostos ergonômicos, desenvolvendo uma atenção mais educada para as complexas questões envolvidas nos diversos aspectos do projeto de um posto de trabalho, o que permitirá que aconteçam menos equívocos nos próximos projetos. Avaliando no conjunto as tentativas frustradas de melhoria da bancada de inspeção de ampolas, percebe-se que os projetos são funcionais do ponto de vista técnico, mas pouco funcionais da perspectiva da atividade de escolha considerada em suas três dimensões fisiológica, cognitiva e afetiva, complexas e inter-relacionadas. A avaliação de algumas tentativas de melhorar o posto existente permitiu evidenciar as inadequações que persistiram devido à incompreensão das características específicas da atividade de escolha.

Aprendendo com essas tentativas malsucedidas e com as análises da atividade real, pudemos explicitar algumas exigências que se revelaram imperativas no projeto da nova bancada. Compreende-se assim por que as inspetoras, ao mesmo tempo em que relatavam o desconforto do posto de trabalho, sugeriam apenas que se mudasse a cadeira. A bancada de escolha atual, apesar de suas inadequações, ainda é a melhor solução que se pode dar às exigências contraditórias da atividade de inspeção de ampolas. Para se chegar a um projeto aperfeiçoado foi necessário considerar as relações dessas exigências com o fluxo da atividade, analisando todo o ciclo de trabalho, do armazenamento inicial ao acondicionamento das ampolas inspecionadas, passando pela dinâmica gestual durante a inspeção visual 
cuidadosa, tal como é feita pelas operadoras, cada uma com estratégias e modos operatórios particulares.

Os postos de trabalho existentes materializam uma concepção do trabalho de inspeção como se fosse estático e simples e assumem uma representação das inspetoras como se adotassem modos operatórios padronizados. Ao contrário, a concepção de uma nova bancada, ao reconhecermos a complexidade da atividade de escolha, se orientou:

- pelas características de complexidade das exigências contraditórias (movimentos, ritmo, postura, proximidade do campo visual, necessidade dos contrastes, armazenamento, preocupação em evitar erros na inspeção, sobretudo os falsos positivos, e risco de acidentes);

- pela natureza dinâmica da atividade; e

- pela necessidade de preservar a variabilidade dos modos operatórios adotados pelos trabalhadores.

Finalmente, um resultado desta experiência enriquecedora para todos que dela participaram foi perceber como a forma do produto se definiu de modo progressivo e interativo, a partir da validação pelos usuários finais, sobretudo depois que foram programados os testes com grande duração. Podemos afirmar, sem receio, que nenhum projeto se desenvolve sem essas idas e vindas. Em projetos, pode-se errar menos, mas não se podem evitar erros. De outra forma, acreditar-se-ia que um produto é a materialização de um projeto conceitual, cuja forma derradeira nada deve ao teste da realidade. Quando se trata da atividade, com mais razão se impõe reconhecer os limites de um projeto, pois os princípios que o orientam, ainda que oriundos da observação e análise da atividade em situação, são apenas um modelo congelado de uma realidade dinâmica. Quando colocados em prática é que se percebe quanto o novo objeto, tal como uma prótese, que sempre se ajusta mais ou menos imperfeitamente ao corpo e aos movimentos, se acomoda às exigências complexas da atividade socialmente situada. Nesse sentido é que todo instrumento de trabalho, como demonstramos com a bancada de inspeção de ampolas, é sempre um objeto social, mais ou menos bem-sucedido em facilitar as interações entre trabalhadores e entre trabalhadores e usuários dos produtos finais.

\section{Artigo recebido em 03/02/2009 Aprovado para publicação em 05/08/2009}

\section{NOTAS}

1. É impossível referenciar todos os autores que nos inspiraram a agrupar as teorias projetuais nesses três paradigmas definidos pela forma de participação do usuário. Além das referências utilizadas (BELLAMY, 1997; IIDA, 1990; RABARDEL, 1995; BÉGUIN et al., 1997; DANIELLOU et al., 1982; THEUREAU, 1992), é necessário se referir, apenas para lembrar alguns conhecidos, a Christopher Alexander, Donald Norman e John. M. Carroll.

\section{REFERÊNCIAS}

BÉGUIN, P.; WEILL-FASSINA, A. et al. La simulation en ergonomie. Toulouse : Octarès, 1997.

BELLAMY, R. K .E. Activity theory. 2 ed. Cambridge: MIT Press, 1997.

BUCCIARELLI, L. L. Designing Engineers. London: MIT Press, 1994.

CAVERNI, J. P. La verbalisation comme source d'observables pour l'étude du fonctionnement cognitif. In: CAVERNI, J. P. et al. (eds). Psychologie cognitive. Grenoble: PUG, 1991.

CHAIKLIN, S.; LAVE, J. (Eds.). Understanding practice. Cambridge: Cambridge UP, 1996.
COELHO, M. M. B.; REIS, R. J. Doenças Músculo-Esqueléticas de Origem Ocupacional dos Membros Superiores. Belo Horizonte: Health, 1998. $124 \mathrm{p}$.

DANIELLOU, F.; DURAFFOURG, J. \& GUÉRIN. Automatiser: quelle place pour le travail humain?. Le nouvel Automatisme, septembre, p. 47-53, 1982.

GUÉRIN et al. Compreender o trabalho para transformá-lo. 2 ed. São Paulo, Edgard Blücher, 2002.

HAGBERG, M. et al. Work related muskuleske/etal disorders (WMSD): a reference book for prevention. London: Taylor \& Francis, 1995.
IIDA, I. Ergonomia: projeto e produção. São Paulo: Editora Edgard Blücher, 1990.

MAGEE, D. J. Avaliação Musculoesquelética. 3 ed. São Paulo: Manole, 2002. 837 p.

NAVEIRO, R. M.; GUIMARÃES, C. P. Uma aplicação da análise biomecânica no processo de montagem de produtos industriais. Produção, v. 13, n. 1, p. 78-90, 2003.

NORMAN, D. The psychology of everyday things. New York : Basic Books, 1998. 
RABARDEL, P. Les hommes et les technologies. Approche cognitive des instruments contemporains. Paris: Armand Colin, 1995.

THEUREAU, J. Le cours d'action: analyse sémiologique. Berne: Peter Lang, 1992.

\section{SOBRE OS AUTORES}

Francisco de Paula Antunes Lima

Universidade Federal de Minas Gerais - UFMG

Belo Horizonte, MG, Brasil

E-mail: fpalima@ufmg.br

\section{Adson Eduardo Resende}

Universidade Federal de Minas Gerais - UFMG

Belo Horizonte, MG, Brasil

E-mail: adson@ufmg.br

\section{Renata Campos Vasconcelos}

Pontifícia Universidade Católica Minas Gerais - PUCMG

Belo Horizonte, MG, Brasi

E-mail: ergon_puc@yahoo.com.br
VASCONCELOS, R. C. A gestão da complexidade do trabalho do coletor de lixo e a economia do corpo. São Carlos, 2007. 250 p. Tese (Doutorado) - Programa de Pós-Graduação em Engenharia de Produção, UFSCar.
VERMERSCH, P. L'entretien d' explicitation. Paris: ESF Éditeur, 1994.

WISNER, A. La méthodologie en ergonomie: d'hier à aujourd'hui. In: CONGRÈS DE LA SELF, 21, Montréal, 1990. Actes. . 